\title{
UNA VISIÓN ICONOLÓGICA DE LA OBRA DE FRANCISCO PEINADO
}

\author{
POR JUAN BOSCO GALLARDO QUIRÓS
}

Teniendo como base la evolución estilística del autor, el artículo persigue que el lector se introduzca a través de los temas e imágenes predilectos, en el universo plástico de Peinado.

Based on the artist's evolution in style, the aim of the article is to introduce the reader into the artistic world of Peinado through his favourite themes and images.

"Sobre el dolor físico como aguijón metafisico abunda la escritura. A mí todo dolor me ataca como arma doble: hace sentir como nunca el divorcio entre mi yo y mi cuerpo (y su falsedad, su invención consoladora) y a la vez me acerca a mi cuerpo, me lo pone como dolor. Lo siento más mio que el placer o la mera cenestesia. Es realmente un lazo. Si supiera dibujar mostraría alegóricamente el dolor ahuyentando al alma del cuerpo, pero a la vez daría la impresión de que todo es falso: meros modos de un complejo cuya unidad está en no tenerla."

J. Cortázar (Rayuela)

"El símbolo no encierra nada, no explica, remite más allá de sí mismo hacia un sentido aun en el más allá, inasible, oscúramente presentido, que ninguna palabra de la lengua que hablamos podría expresar de forma satisfactoria."

C. G. Jung

"Mientras que en la estrella sólo veas una estrella, no tendrás el conocimiento."

F. Nietzsche

El pintor Francisco Peinado Rodríguez (Málaga 1941), vivió parte de su infancia y juventud en el Brasil. Pensamos en este hecho como algo crucial para empezar a entender o mejor, a sentir una gran parte de todo el halo mágico que rodea a sus imágenes. En los arrabales de Sao Paulo su sensibilidad se cargaría como una batería de energía, para infundir a su pintura una pátina distintiva. Allí, en las fabelas, debió 
conocer un ambiente muy especial, muchas veces rayano al peligro, conocería el miedo y seguramente la necesidad. ${ }^{\prime}$

Es difícil para nosotros, inmersos en una Europa que parece temer la unión con otras culturas y donde la miseria con mayúsculas, pasa a ser un hecho aislado, hacernos a la idea de la atmósfera cultural y social en que la personalidad de Peinado, en parte, hubo de desarrollarse; ${ }^{2}$ mestiza en su esencia y alejada para la mayoría de las personas,-entre ellas él y su familia, de una vida placentera, confortablemente burguesa.

Además del sustrato andaluz y malagueño ${ }^{3}$ que luego recuperaría para desenvolverse en él, debemos tener siempre presente los años brasileños. Estos, dejan de ser una simple anécdota biográfica para entender su vida, o lo que es lo mismo, su pintura. ${ }^{4}$

La "batería" a la que me refería antes, se impregnó de sensaciones y vivencias producidas por un contexto singular. Este acervo vital es un elemento potencial, latente, a la hora de crear, es decir; de la fabricación de imágenes.

Al margen de todo esto, es de capital importancia la propia personalidad de Peinado y su famosa y tan subrayada soledad, muchas veces no deseada. ${ }^{5}$ Pensamos que la aceptación de su condición de solitario produce, de alguna manera, la incorporación de valores afectivos, al mundo físico que le rodea; tanto al lugar geográfico donde habita, como a los objetos inmuebles o personales, otorgándoles significados añadidos y exclusivos. La razón última de este proceso de reelaboración semántica de la realidad, quizá sea el cariño a su propia soledad,-aunque a veces se convierta en una herida, el amor a sí mismo y el aprecio por su mundo.

La obra plástica de Peinado se desarrolla a través de óleos, acuarelas, dibujos, y finalmente grabados, ya que nunca ha practicado la escultura.

De los inicios conocemos muy pocas realizaciones, aunque sabemos que gustaba, como tantos jóvenes, de copiar tebeos en una forma más de entretenimiento y juego.

Una vez en España, alcanzó el éxito y se encuadró dentro del realismo fantástico. Durante el período de tiempo comprendido entre la década de los setenta y años

1. "... fuimos a vivir fuera de la ciudad de Sao Paulo que en aquel tiempo era muy peligrosa (...) gritaban como si alguien estuviese herido y después cuando la persona iba a socorrerlo le atacaban (...) vivíamos en una zona de mucha mezcla de gente morena o negra o japoneses..."

ULLÁN, J. M.: Las Soledades de Francisco Peinado, Ed. Rayuela, Madrid, 1977, p. 21.

2. Su estancia americana ocupa de los once a los veintidos años. Es un período largo, en el que el niño va descubriendo su nuevo estado de adulto.

3. "En Brasil hay una atmósfera muy mágica, muy fantástica y eso lo llevo en la sangre. Como también un componente más mediterráneo, dado que mi padre era de Málaga y mi madre de Granada. Yo soy la mezcla de todo eso, y también de un esfuerzo por conectar, por estar al día, por vivir. ..."

FERNÁNDEZ-CID, M.: Francisco Peinado (Premio Andalucía de Artes Plásticas 1992), Junta de Andalucía, Madrid, 1993, p. 13.

4. "La obra de un artista tiene que ser tanto su retrato como el retraro de su vida. La mía ha estado siempre muy presente en la pintura, y creo que cuando mejor pinto es cuando tengo más problemas. ..." Ibidem, p. 19.

5. "No la soledad yo nunca la he querido, pero siempre me he encontrado con ella. Con el paso del los años me voy conformamdo."

MERELO, M. E.: "Francisco Peinado, Pintor", entrevista en el diario "Sur", Málaga, 30-12-94, p. 49. 
finales de la anterior a ésta, la pintura de Peinado se caracteriza por unas composiciones abigarradas, por un horror vacui delirante que le hace llenar la superficie de los lienzos de imágenes insólitas. Monstruosidades animales y humanas se entrelazan provocando superposiciones desconcertantes. El colorido contribuye con tonalidades cálidas a las visiones sofocantes, agitadas, y donde a veces existe cierta dosis de humor. De los tres períodos que estamos delimitando, este primero es el más alejado de la abstracción.

Aproximadamente en los años que van desde 1980 a 1985, es cuando su pintura más a menudo se asoma a los límites de lo abstracto. Sufre un cambio de orientación radical, él mismo ha definido a este tiempo como la "etapa verde" 6 , pero no sólo se producen cambios en el color, ahora más escueto; el dibujo deja de ser tan descriptivo y se simplifica la composición enormemente. El resultado es una pintura que ha perdido el ritmo frenético a cambio de otro más pausado, a veces relajante. Es una pintura menos vehemente y más sabia. En su cojunto, no ha de entenderse como una depuración necesaria, -porque de hecho, conviven obras de nervio, agresivas y violentas, para enfilar el camino de la madurez de la última etapa. Pensamos que el período encierra una entidad propia y que gracias al rumbo tomado, podemos disfrutar de importantes obras; saber de un Peinado pluriexpresivo; asistir al retorno de la acuarela -aparcada tras sus inicios brasileños; y al despertar en sus dibujos, del estilo que le ha convertido en uno de los dibujantes con más personalidad del arte contemporáneo español. ${ }^{7}$

A partir del segundo lustro de la pasada década el malagueño entra en su fase más rica. ${ }^{8}$ La constante que ha sido siempre la calidad de su diseño, permanece como los cimientos donde se edifica la pintura de un artista que vence a la técnica, amoldándola según sus necesidades o capricho. Si como hemos visto fue capaz de jugar con'una paleta más atemperada, ahora se revela como un colorista extraordinario que puede llenar el lienzo de matices inesperados y exquisitos. Nos encontramos ante un artista pletórico, dominador del oficio, creador de sus obras más logradas. Pero hasta aquí, el camino ha sido largo: más de treinta años dedicados en cuerpo y alma, a la pintura.

De la multitud de escritos que en ese tiempo se han publicado. Sólo hemos encontrado un artículo de prensa ${ }^{9}$ que haga referencia expresa al motivo del presente estudio. Pero en él, la autora en seis párrafos escribe tan sólo 'sobre un hecho puntual ${ }^{10}$, mostrando su opinión hacia una exposición en la que Peinado parecía haber evolucionado con respecto a muestras anteriores.

6. FERNÁNDEZ-CID, M. Op. cit, p. 37.

7. "... ya sería causa suficiente como para hacerle merecedor de un lugar destacado en la historia del arte contemporáneo español, me refiero a su portentosa y excepcional disposición para el dibujo."

MARTÍN MARTÍN, F.: Diez Pintores Andaluces, Caja de Ahorros, Códoba, 1991, p. 66.

8. Vid. GALLARDO QUIRÓS, J. B.: "La Plenitud de Peinado", Periódico de Arte y Pensamiento Contemporáneo n. 10, Huelva, 1995.

9. FLÓREZ, E.: "La Iconología de Francisco Peinado", Diario El Alcázar, 5-06-73.

10. La exposición de la madrileña galería Ynguanzo, en Mayo de 1973 y con obras como Pensamiento Hippy, Mar y Cielo, Milagro de Aparecida, etc... El catálogo era de José María Moreno Galván. 
Nuestro objetivo es, a pesar de la versatilidad del artista, ofrecer una visión de la iconología de una pintura compleja, que esconde tras de sí a un padre también difícil, pero que en cualquier caso, ambos resultan de una naturaleza realmente fascinante. Para ello hemos efectuado una revisión exhaustiva de su obra, relacionando entre sí todas las técnicas dentro de las épocas descritas, así como fuera de esos mismos grupos cronológicos y evolutivos.

Entre los motivos recurrentes de las décadas sesenta y setenta, el predilecto es el que llamo "bocas inutilizadas"; calificadas así, porque no les es posible ejercer sus funciones naturales. Están impedidas para comer, succionar, beber, besar o hablar. Podemos inferir que los seres que las poseen están destinados a un considerable estado de incomunicación. No pueden contarnos lo que les ocurre, tampoco sonreir, gritar o simplemente quejarse. Se hallan, por tanto, relegados a la soledad, aislados en un contexto de sufrimiento.

Los caminos para llevar a cabo la incapacidad del órgano bucal son variados. Existen lenguas descomunales que han de salir al exterior, pues su volumen no les permite alojarse en su ubicación natural. Es el caso de una pareja de ambos sexos (Intimidad 1978), que miran sus rostros con el estupor de observarse con tan extravagante deformidad. En otras ocasiones, las bocas son impedidas con mayor sutilidad (El Angel 1978), otras parecen amordazadas, pero las hay sencillamente selladas (Naranja Roja 1973) mediante lo que parecen costurones, brutales huellas de una grapadora o tachones que pueden afectar también a los ojos. Es el caso de un aguafuerte de $1978,{ }^{11}$ donde un ser yace como sombra humanoide en el ámbito de una alcoba y ante la sola presencia de otro monstruo ciego y, acaso, también mudo. La composición es de una fuerza pocas veces vista en ningún otro artista español, una visión espeluznante, terrorífica, patéticamente falta de lógica.

A las "bocas inutilizadas" sigue en reiteración, los "pares de piemas", que no sobrepasan la altura de las rodillas. Es frecuente el aspecto grotesco, cómico (Piernas 1967). En alguna ocasión, sólo vemos unos zapatos que ocupan el lugar de las huellas de las típicas letrinas sin taza de retrete (dibujo $s / t$ 1968), en otras se nos puede ofrecer más información sobre el propietario de las extremidades. (Pensamiento Hippy 1971)

En cualquier caso, ni "bocas inutilizadas" ni "pares de piernas" perdurarán como asunto iconográfico más allá de esta fase también llamada orgánica, ${ }^{12}$ convirtiéndose en rasgos exclusivos del período.

En la "etapa verde" florecen dos temas que le proporcionarán mucho juego en el futuro. Se trata de "la mesa" y "la silla". A partir de ahora y hasta hoy, Peinado gustará de trasladar al lienzo los objetos que le rodean. Como fruto de la depuración estilística, el cuadro puede despejarse y abandonar atmósferas recargadas, así como la proliferación de elementos de apariencia onírica, fantasmagórica o fantasiosa. Surgen entonces, lugares propicios para cierto encantamiento con lo cotidiano, materializándose en obras como un dibujo que representa una desprovista mesita en la esquina de un inhóspito espacio interior. O fijar la atención en una humilde

11. Editado con motivo del cuaderno monográfico que le dedicó la revista Guadalimar en la citada fecha.

12. MARTÍN MARTÍN, F. Op. cit. p. 64. 
silla de madera, (La Silla 1983) plegable, como en las que tantas veces nos hemos sentado en terrazas, cines de verano o bares de playa, sin reparar en la sinceridad de su utilidad, en el acierto de su falta de pretensiones dentro del contexto mobiliario que nos envuelve, tantas veces, presuntuosamente kitsch. Es, una vez más, la sensibilidad de un artista, la que nos permite ver más allá, invitándonos a aprehender el mundo con la forma y colores por el deseados (el principio básico del espírutu de la pintura).

Como se ha señalado, desde aproximadamente 1985, Peinado lleva diez años en la plenitud de su condición de creador. La detención ante objetos y enseres comunes continua, pero ahora sillas, mesas, lámparas, mesillas de noche, ventanas divididas en cuatro cuadrados iguales etc... forman parte del atrezo con el que los "actores" nos cuentan sus historias, agrupándose y asumiendo un papel primordial, ya que no sólo informan de dónde, sino también de qué y como está sucediendo. Es aquí donde cabe hablar de pintura narrativa. ${ }^{13}$

A partir de ahora, aparecen elementos iconográficos nuevos que contribuyen a conformar la imagen del Peinado "clásico". Sobre los lienzos, maderas y papeles, comienzan a edificarse las "grandes arquitecturas" que pueden llegar a ser fantásticas y enigmáticas (Castillo 1989), nunca vistas en la realidad; o hermosamente ingénuas, pequeñas, amarillas, rodeadas de blandos y colosales árboles (Castillo Amarillo 1990).

Las concentraciones de edificaciones pueden ser poblados, aldeas de escaso empaque (Haifa 1991), o incluso poseer aires Neoyorquinos, (Avión en el Tejado, Ahorcado de ciudad 1988).

También existen torres monumentales, (La nave 1988) deliciosamente ilogicas por definición, -pues sus nombres no responden a la forma que ofrecen, atalayas para divisar no sabemos bien qué horizontes; metáforas quizá, de nuestros empeños y afanes reflejados en la actividad de los pequeños hombres que las coronan o erigen.

A las casas del mismo arquetipo que dibujan los cuentos infantiles (Casa del Cóndor 1987), podemos contraponer edificaciones con aires de arquitectura religiosa, con chapiteles a cuatro aguas de cierto recuerdo medieval. ${ }^{14}$

Por su condición de hitos, relacionables a las "grandes arquitecturas", son los nuevos "Postes", que proliferan bajo diversas modalidades. ${ }^{15}$ Siendo el común denomiador su forma y disposición verticales, con lo que se contraponen, en general, a la horizontalidad de sus ubicaciones. Aquí también podemos ver una posible relación con el lugar topográfico donde habita el hacedor de todas estas imágenes. "Pinos de Alhaurín" (Alhaurín de la Torre, Málaga), lugar de residencia del pintor,

13. Me refiero a la tan comentada plástica autobiográfica narrativa de Peinado, que necesita desglose y matización, pero que deseo realizar en otro lugar, (en la actualidad me encuentro realizando la tesis de licenciatura sobre el artista malagueño), para no dispersar el centro de este artículo. .

14. Presentes, por ejemplo, en la magnífica serie de acuarelas y dibujos realizados en Alemania, entre finales de 1989 y principios de 1990.

15. Postes de teléfono: Eclipse (1991). Cercas: La Granja (1989). Arboles siniestros, asociados a cabezas autónomas (comentaremos éstas más abajo): Jardín de los Inocentes (1993). Difíciles de precisar pero, en cualquier caso, gruesos, gigantes, maleables y filiformes: La Cerca (1990). Cercas y banderolas que rodean un lavabo: Encuentros (1993). Cucañas coronadas por pequeñas hélices: Molinos (1991).

Como se ve, el grupo es muy heterogéneo. 
es una urbanización apartada, de orografía montañosa. "Manchando" la vegetación, las casas se disponen a diversas alturas. Los cables telefónicos y eléctricos conectan las arquitecturas a través de estructuras que se suceden salvando, por sus considerables dimensiones, lo abrupto del terreno. Posible transferencia a sus obras del medio donde vive o simple fascinación nuevamente, hacia cosas carentes, en principio, de valores estéticos per se.

En esta línea de rescate de la indiferencia a cosas intrascendentes iniciada en la segunda época, hay que entender el tema del peine, una de cuyas interpretaciones más emblemáticas es el espléndido lienzo El Barco del Peine (1987). En este caso, la mano noble del artista ha actuado como una lente engrandeciéndolo, para que fijemos nuestros resortes sensitivos, en la realidad callada del objeto. Pero este peine rebasa el simple hecho mimético de reproducción: convirtiéndose en un signo personal. A nadie se le escapa la similitud fonética del primer apellido del malagueño con el instrumento que a diario asimos para emprender el gesto mecánico -me gusta pensar que ritual, de poner en orden nuestros cabellos, en el cuarto de baño, mirándonos, frente al espejo.

En otra obra (Mujer Peinándose 1987), un personaje femenino de expresión ensimismada, junto a un niño de mirada recelosa, sostiene el mismo "objeto-emblema" sobre su cabeza. Juego conceptual de una mujer que se acaricia el pelo, con el propio nombre del artista.

En este pequeño grupo de obras alegóricas marcadas por la afectividad, podemos incluir a una letra, " $m$ ", embarcada como en el caso del peine y posible referencia al nombre de una antigua compañera sentimental, que comenzaba por aquella letra, visible en el óleo de título homónimo fechado en 1991.

Existen otras imágenes recurrentes como los "barcos". Todos sugerentes, sencillos, embarcaciones reducidas muchas veces al mínimo concepto de cosa que ha de flotar, inmersos casi simpre en pequeños mares, encabritados algunos, en una suerte de océanos de juguete (Haifa 1991). Barcos y mares llenos de poesía, de misterio y encanto: Naves de vapor que surcan barreños (El Puerto 1989) y -como hemos comentado, portadores de una " $\mathrm{m}$ ", veleros cuya mesana es un enorme peine. Diseños de tan difícil operatividad como extrema belleza.

En realidad, las máquinas peinadianas siempre han gozado de una dudosa eficacia. Es un rasgo que, salvo excepción, surge en la segunda etapa. En este período observamos por ejemplo, automóviles y artefactos voladores condenados irremisiblemente al fracaso. También en el Peinado de a partir de la segunda década de los ochenta, están presentes los ingénios desastrosos que pueden tener como precedente ilustre y remoto a las máquinas dadaistas. Aquellas eran metáforas del desatino histótico, la dislocadura del siglo $\mathrm{xx}$, pero nosotros hemos atrofiado las sorpresas del vértigo contemporáneo. Probablemente los trebejos de Peinado sean el producto de la asunción sin acritud de algo más profundo, el absurdo universal: el mundo funciona mal pero todo encaja; la perfección del azar; nuestra libertad sin límites; nuestra limitación absoluta... 
Lo absurdo es un principio inmanente en el arte de Peinado e, integrante, de una trilogía que se complementa con el dolor y el misterio. Desde estas tres coordenadas abordo la iconografía de lo que podemos denominar como "las cabezas autónomas". Su presencia puede remitirnos al desconcierto, -es el caso de las que se inmiscuyen en algún juego infantil (La Granja 1989); asociarse a cuerpos quiméricos (Autoescorpión 1989); o sencillamente parecen sufrir (Latiguero 1989). En cualquier caso, no se tratan de cabezas cortadas o desprendidas a la manera de la del Bautista. No reposan sobre ninguna superficie ni humano cuerpo. Vuelan, se desplazan autónomamente para actuar a su antojo o sólo hacer de enigmáticos mirones. Están en relación con otro conjunto de imágenes: "los torturados".

Crucificados, ahorcados y personas que reciben o se disponen a recibir los efectos de objetos cortantes, comparten el trágico destino de su sufrimiento. Están condenados a padecer, incluso en contextos a los que previamente les asignamos caracteres de placidez, al menos de inocuidad, como son las reuniones familiares (Juegos de Cuchillos 1989).

Contrariamente a lo que pensábamos a priori, el ahorcado no es una imagen frecuente, pero lo contundente de su presencia es la razón que nos hace incluirlo, aunque sólo sea en forma de mención. Más utilizados son los crucificados. En ellos la expresión "varón de dolores", puede llenarse de su contenido más hondo, (como puede observarse en un dibujo fechado en 1986), hasta el extremo de fundir su carne con el madero, formando un único amasijo (Tres Cruces 1990) También es posible la asociación con otras imágenes (Cristo del Pez 1993) o intervenir como conformador, al igual que otros elementos más arriba señalados, del atrezo.

Sin embargo, camas y retretes son las imágenes predilectas de nuestro artista. Ambas son las más reproducidas a lo largo de su trayectoria. ¿A qué puede deberse tal fascinación?

En la tradición cristiana, la mesa, el lugar de rezos, y la cama eran los tres altares del hogar familiar. ${ }^{16}$ La cama es el lugar donde pasamos buena parte de nuestra existencia. En ellas dormimos para descansar y soñar, mantenemos relaciones sexuales, llegamos incluso a comer, sobrellevamos enfermedades físicas y mentales y, finalmente, es donde solemos venir al mundo y dejar de vivir.

Problablemente se trate del útil más unido a lo humano y uno en los que no se detiene casi nunca nuestra antención. Con seguridad, porque siempre está ahí, abrimos la puerta del dormitorio y nos desnudamos para dejarnos caer y yacer. $Y$ es que si observamos bien, estamos irremisiblemente atados a las camas, incluso nuestra tumba o el vientre materno son en el fondo otras formas del lecho donde encontramos reposo ya para la vida o la muerte.

Alcobas. Lugares cargados de fuerza, cajas para el sueño y el deseo, escenarios de nuestros sufrimientos y placeres. Rincones mágicos de nuestras casas, citas con el misterio de nuestro propio ser y la innegable existencia del sexo y la muerte.

16. Buena parte de los dormitorios están presididos por un Crucifijo como elemento tutelar. Hecho que también observamos en algunas obras de Peinado, como La Trini 1989, o un dibujo de 1989, de enorme interés desde el punto de vista de nuestro estudio iconológico. 
Cama y alcoba nos resultan, particularmente, lugares de una riqueza semántica y simbólica extraordinarias. El artista se acerca a ellas como tal, no para definir ni delimitar, sino para sentir y hacer sentir.

El repetorio de concreciones plásticas es muy variado, entendiendo siempre a la cama como el centro del alcoba. Tenemos lechos para el horror (Grabado $s / t$ 1970-77), para el sexo ${ }^{17}$ (Antes de Acostarse 1977), para lo ignoto (El Grito de Malaquías 1993) o sencillamente, lechos imposibles (Interior sin Figuras 1989).

El retrete es elgo así como el esclavo romano cuya misión era recordar a los triunfadores lo transitorio de su gloria. Posee la virtud de ponernos a diario en la realidad de nuestra fisicidad y, por tanto, de nuestro fin. En él depositamos nuestros fluidos, heces, mucosidades, pilosidades... cosas que son o han surgido de nuestro propio cuerpo y que esperan que se les lleve el agua, encerrada, mediante una obediente cascada. ${ }^{18}$

Como en el caso de la cama, su emplazamiento es un espacio que, si nos detenemos con interés, resulta estimulantemente evocador. Me gustaría resaltar el hecho palpable de que en los cuartos de baño hay agua, símbolo esta última inconmensurable, que hace referencia tanto a la vida como a la muerte y a la capacidad de resurgir, de resucitar. ${ }^{19}$

No sólo en Peinado se da la atracción por los cuartos de baño. ${ }^{20}$ Es el caso de artistas que van desde Antonio López a Stanley Kubrick. El cineasta gusta de elaborar escenas enigmaticamente bellas en filmes como "El Resplandor" o "La Naranja Mecánica". Para ello, ha sabido encontrar las cualidades plásticas innegables de los aseos: la pulcritud, asepsia, monocromía, brillos, reflejos de luz o imágenes en los espejos, reververaciones sonoras y la presencia siempre latente y

17. Con respecto a la sexualidad, nunca aparece de forma explícita. Los desnudos manifiestos como Capa Verde (1990), no proliferan y en ningún caso son masculinos.

Peinado considera de mal gusto el sexo evidente, prefiere sugerirlo, (declaraciones en entrevista personal realizada en Alhaurín el 16-09-95).

18. Me refiero evidentemente, a la cisterna ordinaria. Sin embargo, existe otro sistema en el que el agua no cae en chorro desde el depósito, sino que se acumula para una vez llena la taza, salir en forma de torbellino. Esta última modalidad es aun más plástica y me hace pensar en una acuarela, que no parece representar un inodoro, pero si guarda una forma similar a la de un váter, y en cuyo centro se haya una espiral.

19. "Las aguas, masa indiferenciada, representan la infinidad de lo posible, contienen todo lo virtual, lo informal, el germen de los gérmenes, todas las promesas de desarrollo, pero también todas las amenazas de reabsorción. Sumergirse en las aguas para salir de nuevo sin disolverse en ellas totalmente, salvo por una muerte simbólica, es retornar a las fuentes, recurrir a un inmenso depósito de potencial y extraer de allí una fuerza nueva: fase pasajera de regresión y desintegración que condiciona una fase progresiva de reintegración y regeneración (-baño-bautismo)."

CHEVALIER y GHEERBRANT: Diccionario de los Simbolos, Ed. Herder, Barcelona, 1988, pp. 52-53.

20. Cuarto de baño y sus componente mobiliarios los ha representado en multitud de ocasiones y maneras. Tan sólo como ejemplos: El Lavabo (1976), donde se limita a una somera descripción; Ventanita del Váter (1980), buena muestra del procedimiento de síntesis de la época. Aluden a la concepción del lavabo como centro donde puede ocurrir lo extraño: Come Plomo (1991); María Candelaria (1989). O también, como ya hemos visto, el simple hecho de pintar las cosas que le rodean: La Bañera (1986). 
sugerente del agua. Continuando con la séptima de las artes, Bigas Luna diseña para la conclusión de "Huevos de Oro", una lucha entre el ya decrépito "macho" y un bidé -elemento "hembra". Por último darnos cuenta de que la historia del arte contemporáneo no podría entenderse sin el sencillo urinario que contribuyó a derribar los ciminetos de la tradición. ${ }^{21}$

La alcoba y el cuarto de baño son ámbitos simbólicos inefables, secretamente instalados en nuestros hogares. Para el caso de los aseos, hay un concepto de fondo que constituye la esencia de la funcionalidad y última razón de ser del retrete: el agujero, la abertura que todo lo enguye ${ }^{22}$ y de la que no conocemos el otro lado. De hecho, de los cinco dispositivos que pueden hallarse en los aseos, -lavabo, bañera, plataforma de ducha, bidé o inodoro, no son más que recipientes que albergan un orificio por el que se pierde el agua sucia, en la que marcha flotando o diluida, una ínfima parte de nosotros.

Mas, para Peinado, esta ida puede ser también vuelta. El hombre sube del desagüe de un lavabo. ${ }^{23} \mathrm{Ha}$ comprendido la unidad de contrarios en un símbolo escatológico: el agujero de donde veninos y a adonde vamos en viaje de ida y vuelta; el umbral del más allá y el más acá; el mismo agujero femenino del que surgimos $y$ en el que hay que volver a entrar, para volver a nacer.

21. Recuérdese la famosa "Fuente" de Marcel Duchamp. Sobre su valor plástico paso a copiar un extracto de la soberbia monografía española sobre este autor clave de las Vanguardias Heróicas.

"... Esta clase de similitudes fueron publicadas por primera vez en el artículo de Louis Norton, quien escribió: ¡Que placentero es, para cualquier ojo inocente, observar su casta simplicidad de línea y color! Alguien dijo: "Como un Buda encantador"; Alguien dijo: "Como las piemas de las mujeres de Cézanne". ¿No le han recordado siempre esas mujeres, en su curvilínea y completa desnudez, a las suaves curvas de las decadentes porcelanas de fontanería?".

RAMiREZ, J. A.: Duchamp el Amor y la Muerte, incluso Ed. Siruela, Madrid, 1993, p. 55.

22. A este respecto, existe un grabado (S/t. de 1995) muy revelador. Representa el agujero de un váter completamente oscuro y tragador de todo. Por él se están perdiendo elementos muy significativos como un crucificado, cuchilla, peces. (Existen también otros elementos iconográficos recientes como clavos o la escritura para no pensar).

Peinado ha creado reiteradas veces a partir de la idea de un agujero enigmático. Es el caso de Water Amoroso (1992), o La Torre (1991). En ocasiones podemos relacionarlo con el sexo femenino, en Doncella del Anillo (1989), una muchacha posee entre sus piernas un gran anillo, que nos habla de la propia vagina que no podemos ver. De mayor riqueza es Con el Maxilar Izquierdo (1988), donde un varón se inclina para mirar a través de un círculo lleno de agua. Arriba a la izquierda conocemos el contenido de su visión: en el interior de un remolino se hallan unas piernas femeninas cortadas a la altura del sexo.

23. Hago referencia a Ascensión (1994), integrante de la serie "escritura para no pensar". Si atendemos al título de la obra, quiere decir, que el personaje masculino sube partiendo del agujero del lavabo. Por otra parte, el cuadro es en sí otro gran agujero que se articula a través de las estacas, postes y cables telefónicos que ya conocemos. Asimismo, existe otra obra que ayuda a entender que el regreso es posible. Se trata de un dibujo ( $S / t$ 12-12-89), que nos muestra como un trebejo volador peinadiano, surge de un gran y oscuro agujero. 


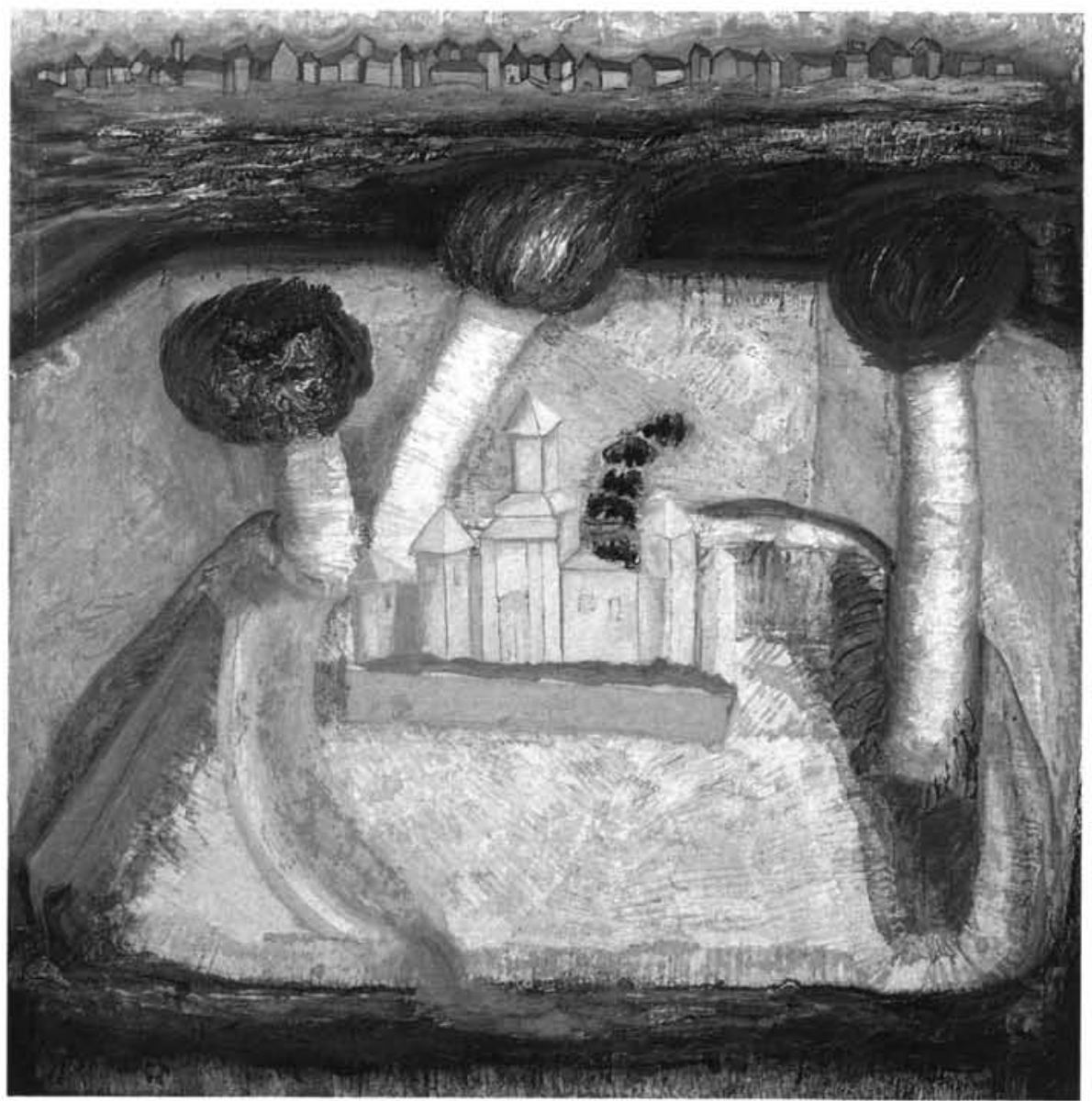

Ilustr. 1.

Castillo Amarillo. 100x100 cm. Óleo sobre tela y madera. 1989. Junta de Andalucía 


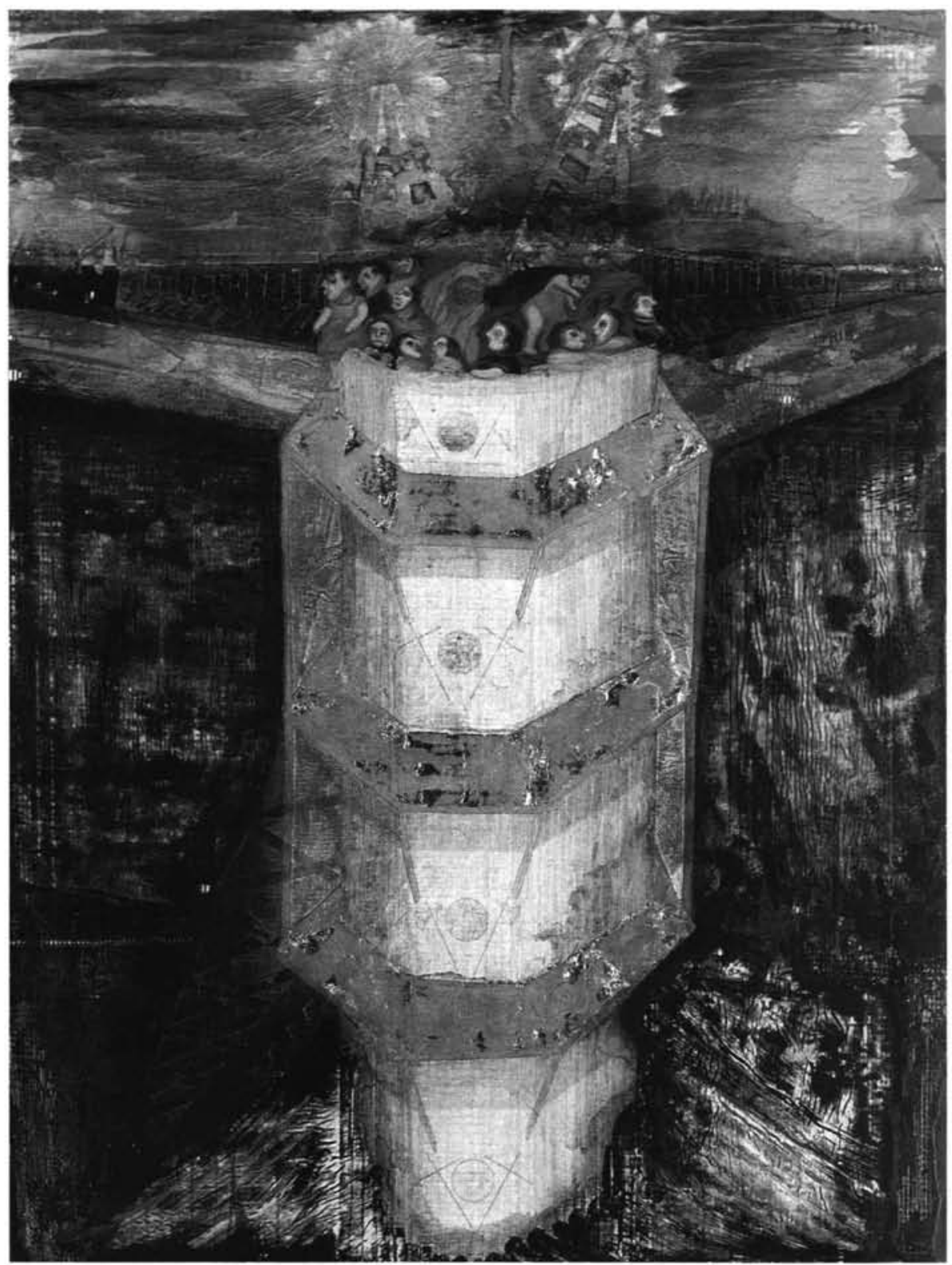

Ilustr. 2.

La Nave. $160 \times 122 \mathrm{~cm}$. Técnica mixta. 1988. Colección privada, Chicago. 


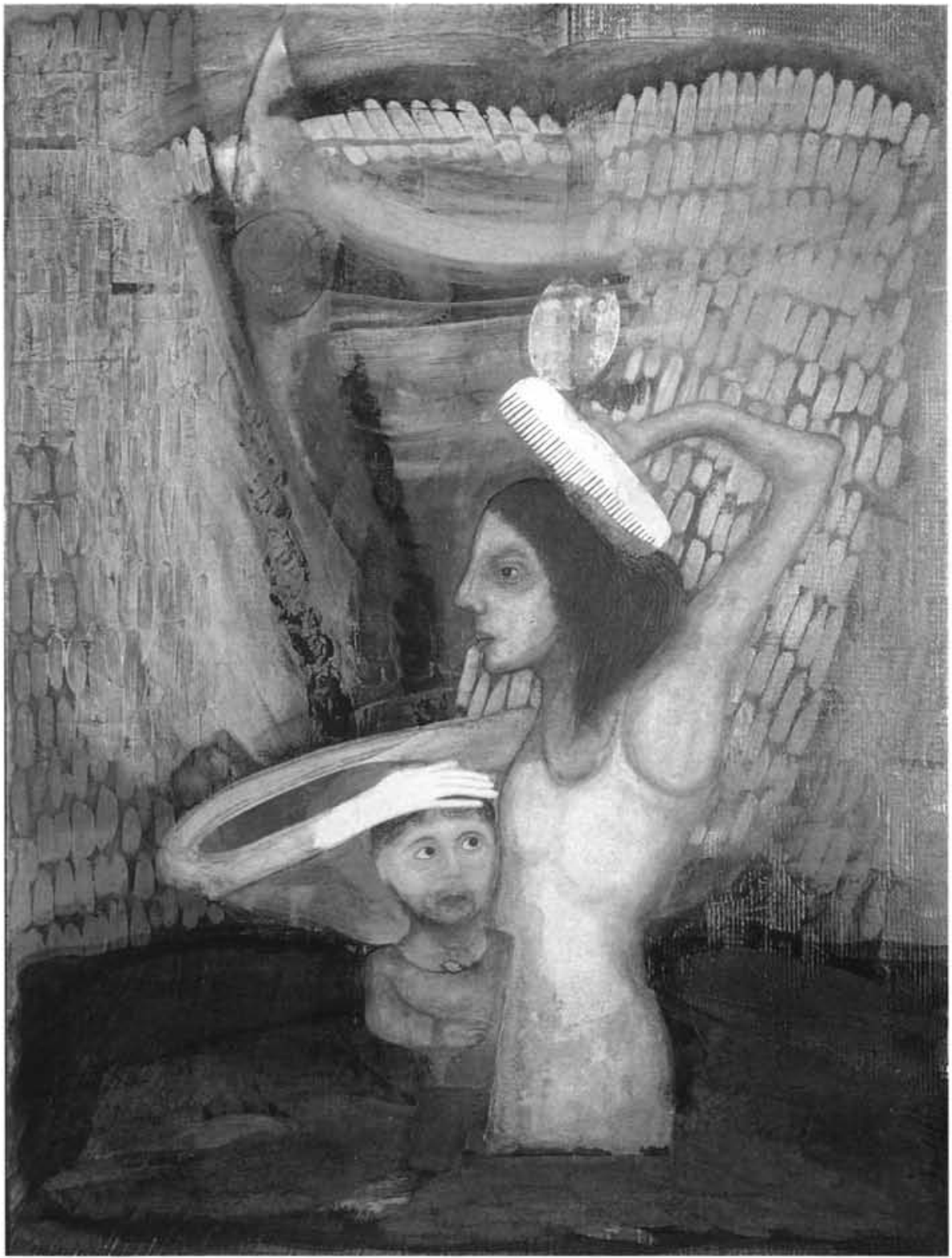

Ilustr. 3

Mujer Peinándose. 160x121 cm. Técnica mixta. 1987. Colección privada, Madrid. 


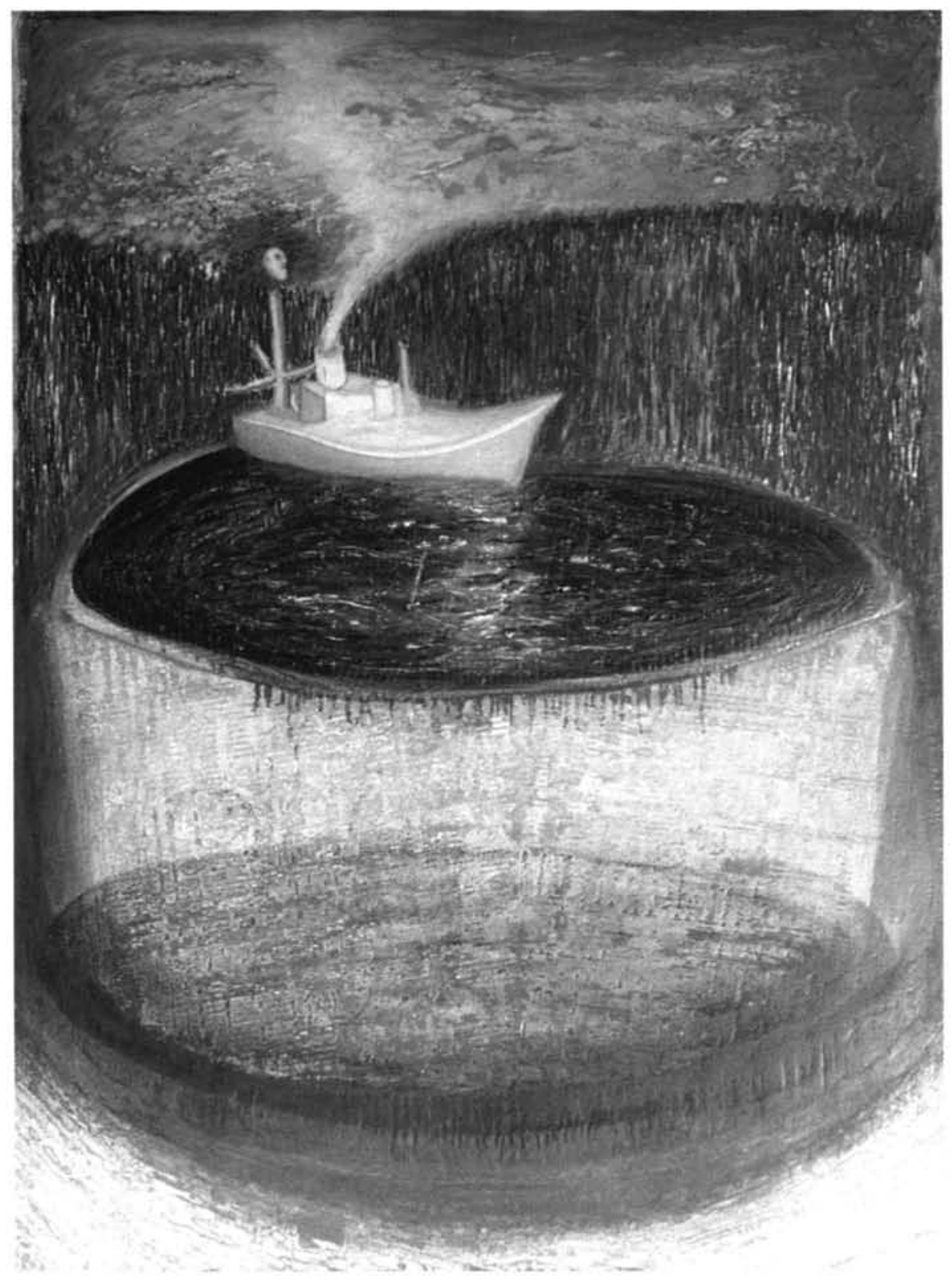

Ilustr. 4 .

El Puerto. 130x98 cm. Óleo y cartón sobre lienzo y madera. 1989. Colección privada, Suiza. 


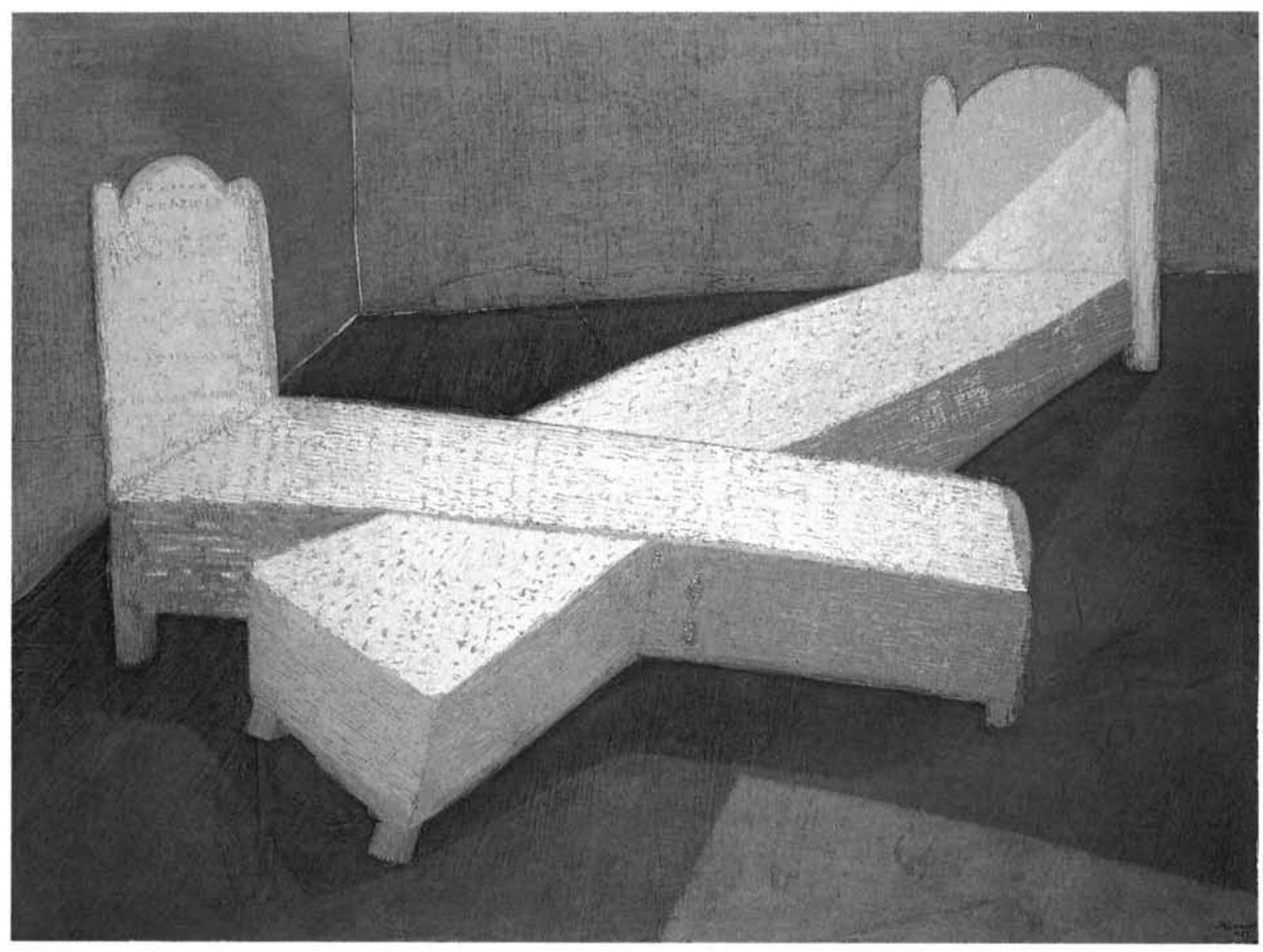




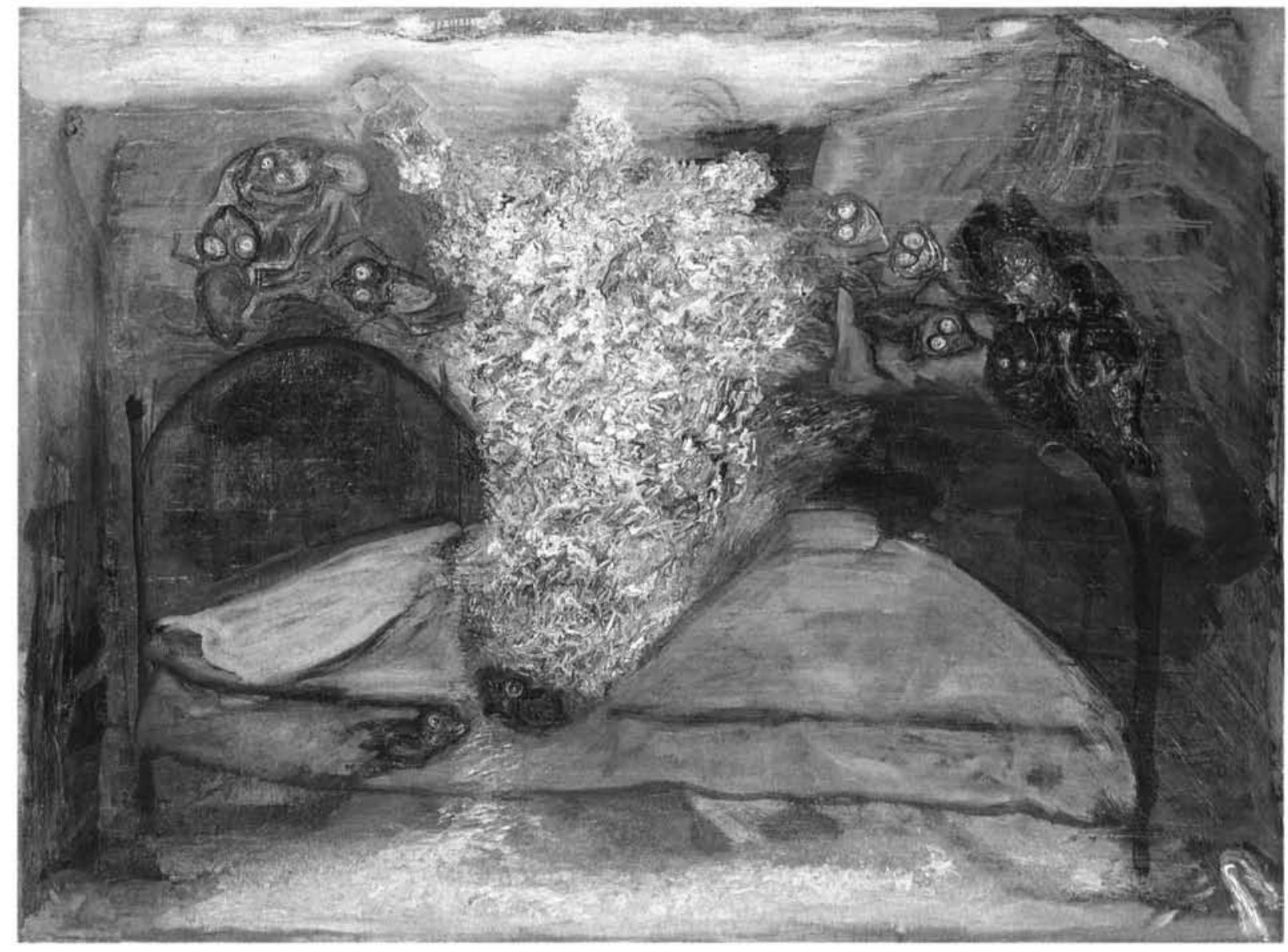




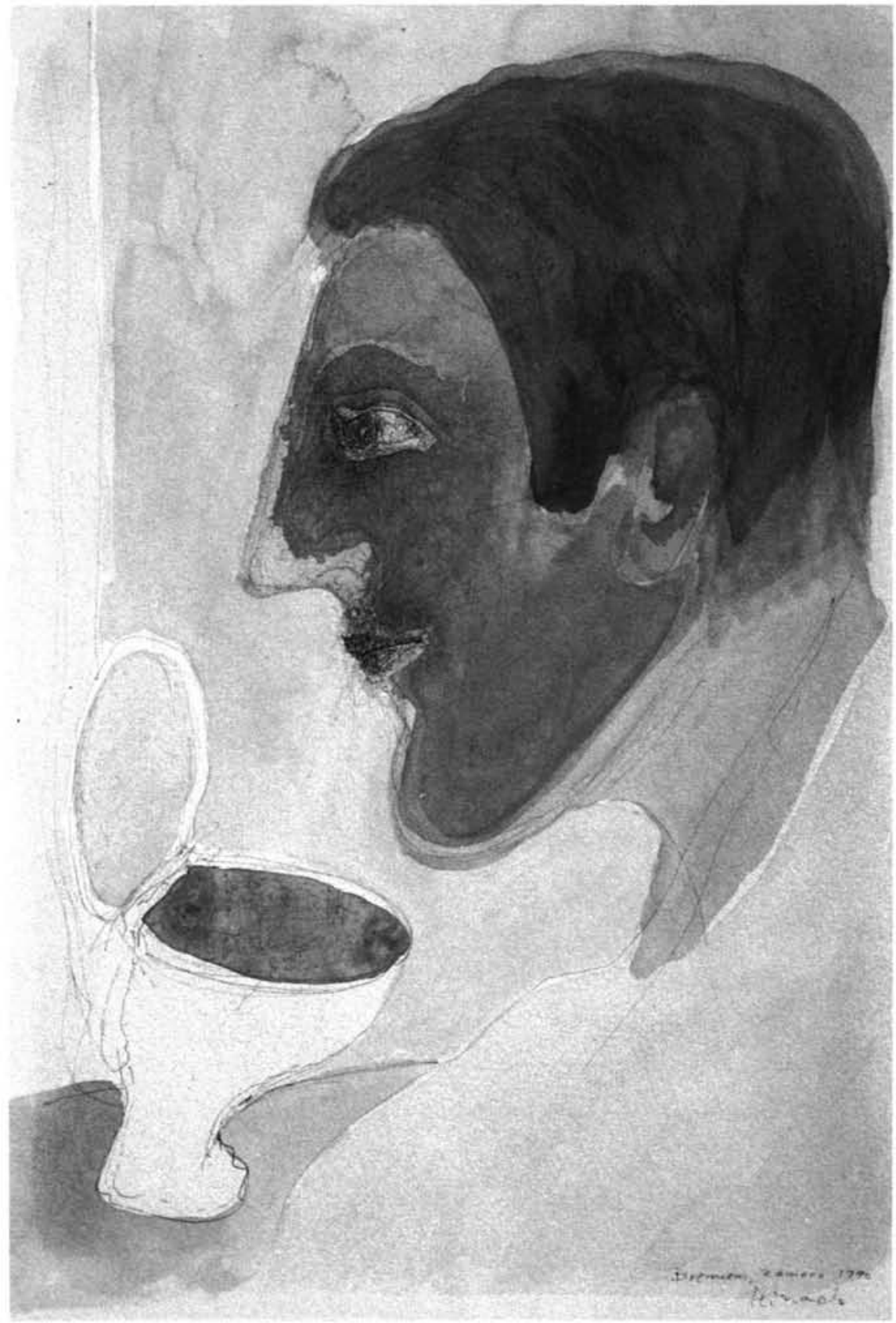

Ilustr. 7.

Váter. $32,5 \times 22,5 \mathrm{~cm}$. Acuarela. 1990. Colección del artista. 


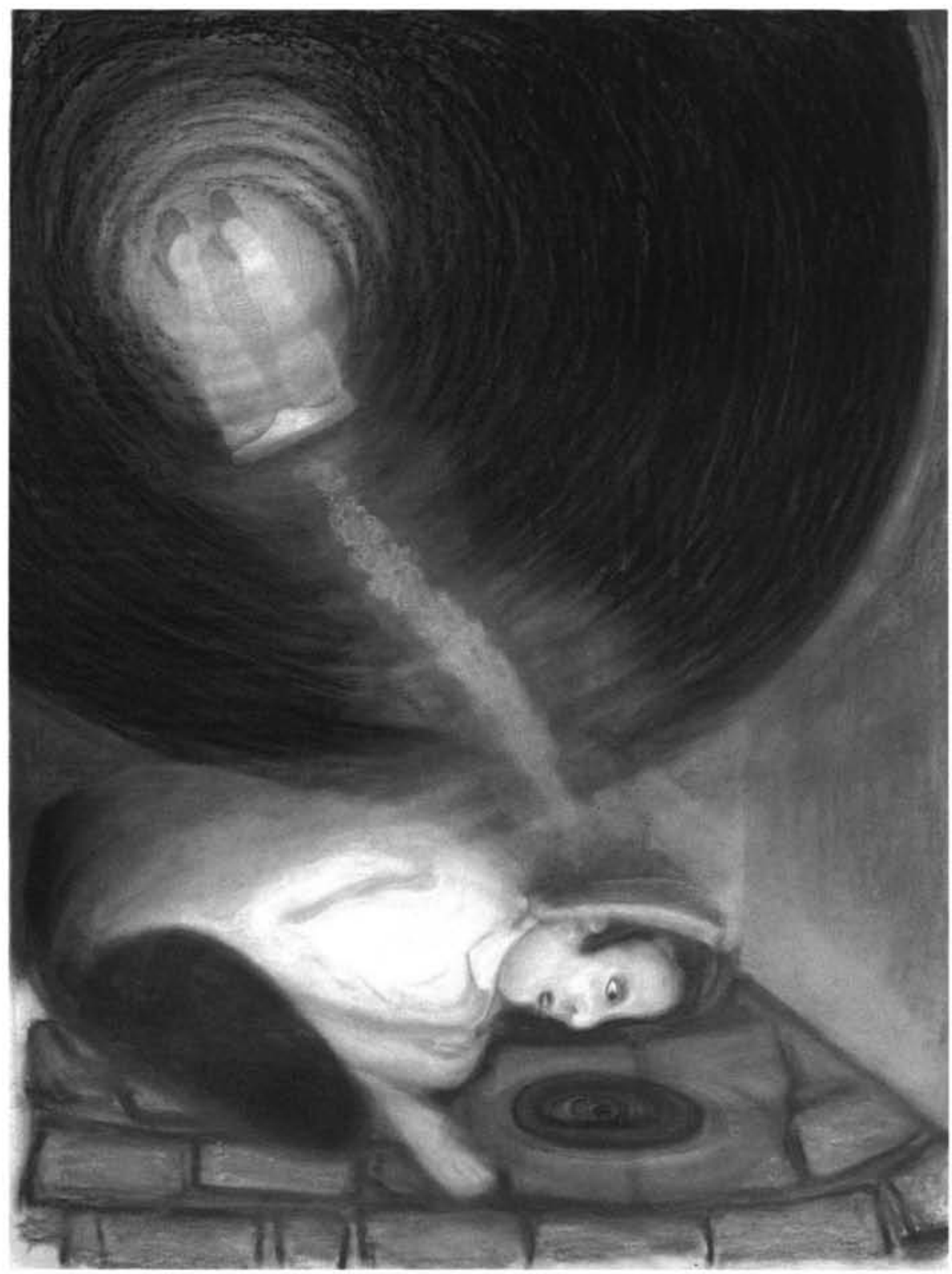

Ilustr. 8.

Con el Maxilar Izquierdo. 160x121 cm. Pastel sobre papel. 1988. Colección privada, Madrid 


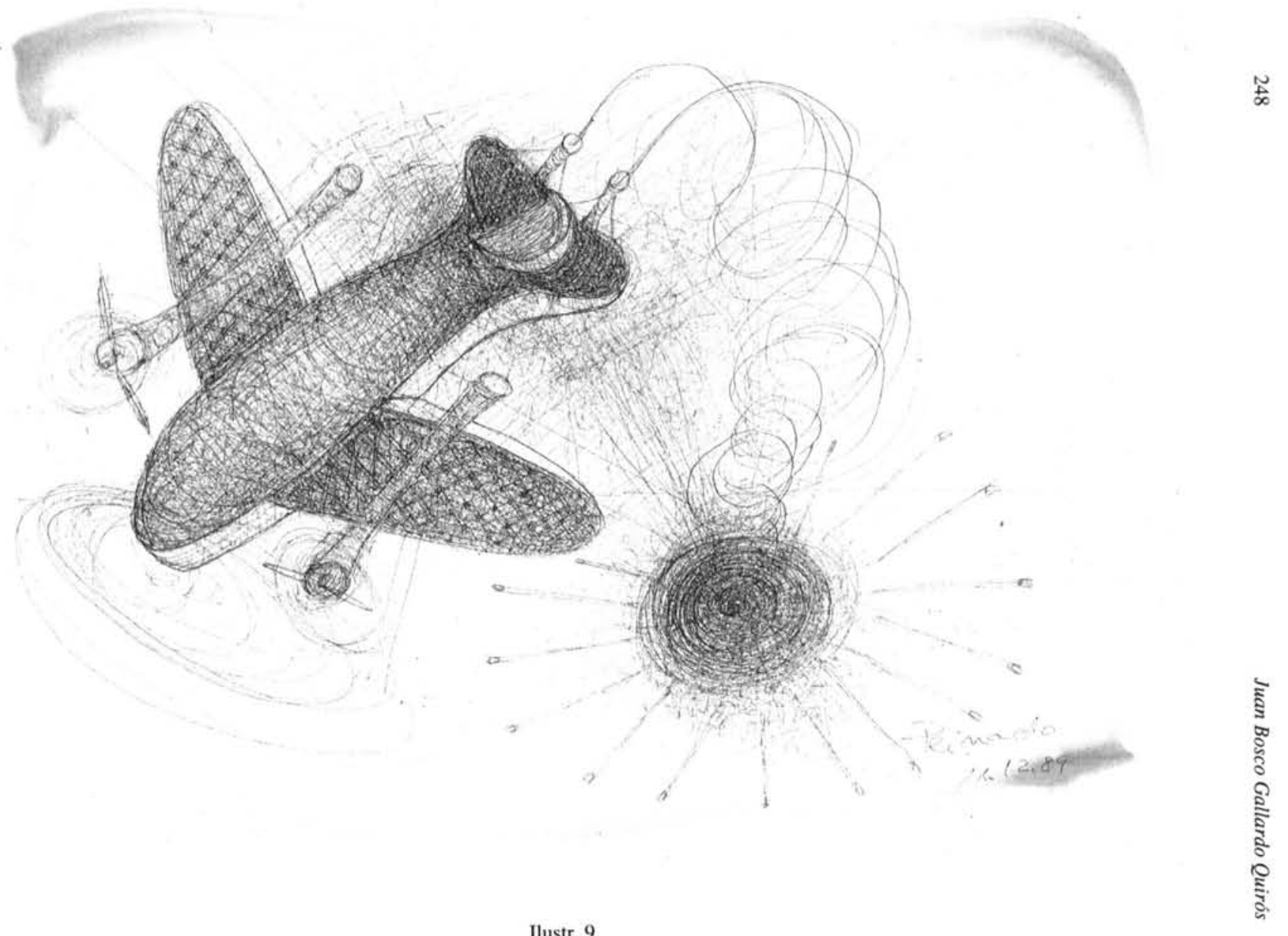

Sin Título. 16×22,4 cm. Dibujo a plumilla. 1989. Colección del artista. 


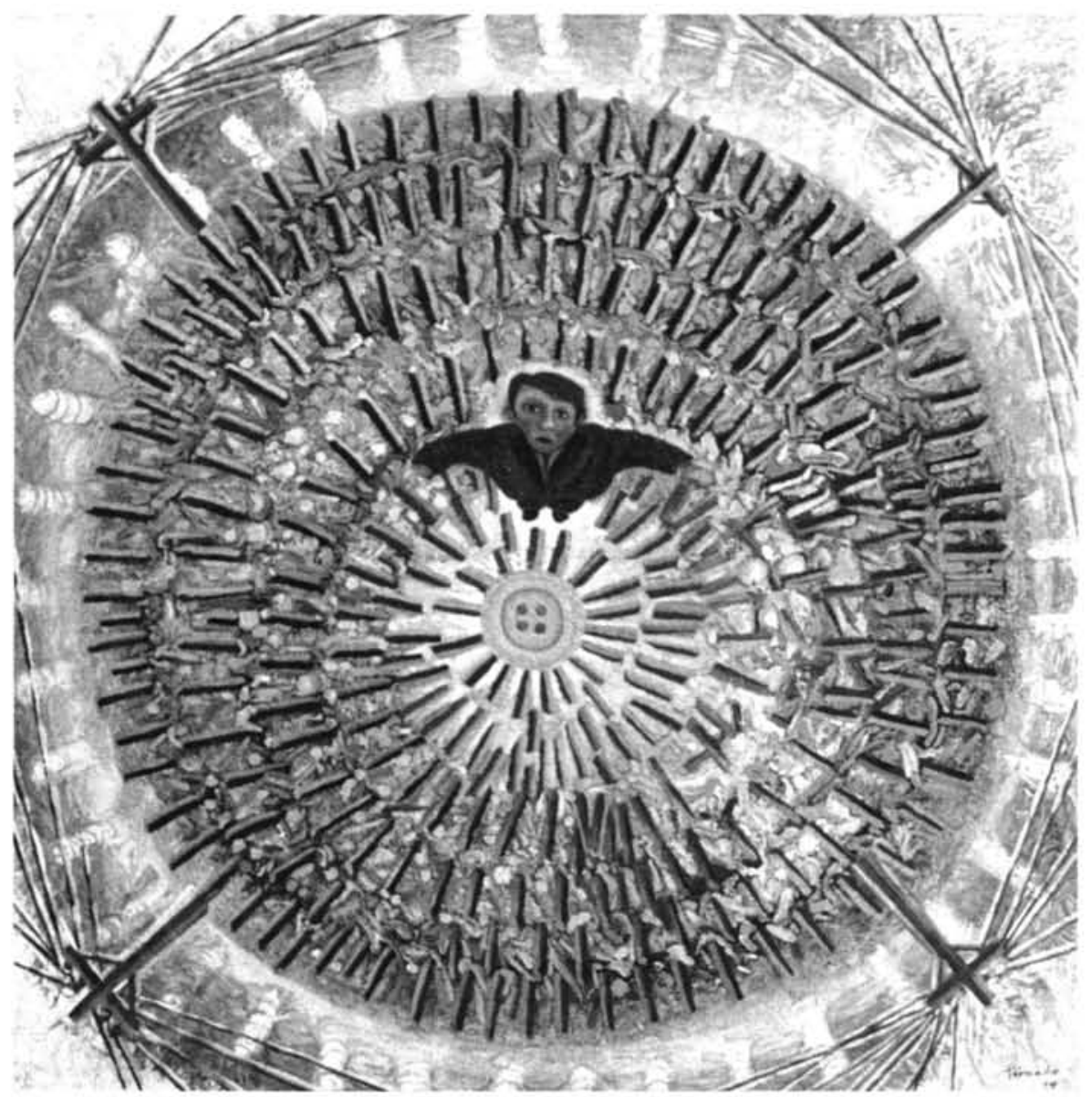

Ilustr. 10.

Ascensión. 100x100 cm. Óleo sobre lienzo. 1994. Colección del artista. 